\title{
DIMITRIS TSAROUHAS
}

\section{Frame Extension, Trade Union Identities, and Wage Politics: Evidence from Sweden}

\begin{abstract}
Drawing on frame theory, this paper examines how policy entrepreneurs within the Swedish Trade Union Confederation Landsorganisationen $i$ Sverige (LO) embarked on a campaign to extend an exclusively class-based solidarity frame along gender lines. In the process, LO's identity was modified. Once the new solidarity frame had been accepted, it was operationalized in the collective bargaining process through the creation of a "women's pot"-i.e., a wage supplement given to female employees, or female-dominated sectors, to counter gender-based pay discrimination. Nevertheless, the new frame has yet to meet with success in the wage-bargaining arena, as LO faces problems of intra-union coordination in an unfavorable institutional context.
\end{abstract}

Over the last decades, trade unions have been under double pressure. On the one hand, the restructuring of the world economy and concomitant changes in production and labor markets have made employment prospects more uncertain, recruitment more difficult, and job security more precarious. The current economic crisis 
serves as a potent reminder of the above and highlights the importance of organized labor in times of uncertainty. On the other hand, unions have also been struggling with internal problems centered on dissatisfaction with union performance and a disconnection between the rank-and-file and union elites. As traditional employment and production patterns change, trade unions have failed to live up to the expectations of their new, more diversified constituents (Lévesque, Gregor, and le Queux 2005, 401).

This twin set of challenges has given rise to a rich literature on trade union renewal and the formulation of alternative strategies for recovery (Baccaro, Kerstin, and Trurner 2003; Fairbrother and Yates 2003; Frege and Kelly 2003; Turner, Harry, and Hurd 2001). Among the most significant of these is the need to give expression to new forms of solidarity and mobilize potential adherents. The feminization of the workforce is particularly pertinent in this regard, as the combination of a feminist and trade union identity inside the labor movement has the potential to rekindle union renewal attempts.

This article addresses the question of trade union identity by analyzing how the Swedish Trade Union Confederation (Landsorganisationen i Sverige, LO), the country's largest confederation that brings together fifteen trade unions and approximately 1.5 million members, has responded to the rise of the feminist movement within its ranks. LO had traditionally operated in a centralized manner that conceived solidarity solely along class lines. An increasingly feminine workforce, concentrated in the public sector, however, campaigned for gender equality in public life and sought to place gender at the heart of trade union operations. In the process, it has not only given rise to a new set of demands to make gender equality commitments more concrete, it has also renewed the ideological and organizational repertoire of LO as a whole.

This paper draws on framing theory to show how the master frame of (class) solidarity on which LO had traditionally relied was extended by feminist policy entrepreneurs to address the changed conditions of the Swedish labor market. Solidarity was reinterpreted away from its gender-neutral meaning toward a new inclusiveness that saw female union members as doubly disadvantaged by class and gender. The new definition of solidarity has been expressed in the form of a "women's pot," with the aim of securing higher wage increases for women and countering gender-based injustices in remuneration.

The argument is twofold. First, female policy entrepreneurs within LO embarked on an innovative frame extension process through which they sought to redefine the traditional frame of 
solidarity to encompass gender as well as class. This framing process and the ongoing battle for wage equality facilitated union revitalization through the use of innovative campaign methods and a new emphasis on decentralized unionism. Second, gender-class solidarity in wage bargaining remains a work in progress. Resistance to the idea is derived from the unwillingness of some unions to countenance positive discrimination for women's wages. The diverse membership base of LO's most powerful unions, the formation of new wage coordination structures, and institutional obstacles derived from recent political changes mean that the issue of how to achieve gender-based wage parity remains contentious. This underlines the significance of explaining collective action by looking at the interaction between structural/organizational factors and cultural/framing processes (Diani 1996; Franceschet 2004).

The paper is structured as follows. I begin with a discussion of trade union identities and collective action theory, focusing on framing processes. I then outline the original conditions of LO's development based on the master frame of class solidarity before analyzing the emergence of gender as an organizing concept for female union activists. The next two sections analyze the successes and limits of the exercise, respectively, while the conclusion summarizes the main argument and offers some reflections on trade union renewal through collective mobilization.

\section{Trade Union Identities}

The issue of trade union revitalization is linked to the functioning of trade unions in democratic societies. While unions have been under pressure since the 1980 s, it is important to remember their potential contribution to lower unemployment (Calmfors and Driffill 1988) and social peace through consensus-based economic reform (Hamann and Kelly 2007). More broadly, trade union revitalization is important as unions are an integral part of industrial relations systems and their weakening can have a decisive impact on national economic systems and welfare regimes (Behrens, Hamann, and Hurd 2004). One of the ways unions can recover lost ground is through the adoption of gender framing. This has happened in the Swedish trade unions.

More than thirty years ago, Clegg (1976) underlined the existence of a link between institutions of industrial relations and the pattern of trade union organization, paying special attention to collective bargaining processes. Such institutionalist approaches are charged with attributing too great a role to institutional arrangements ("path 
dependency") and ignoring the potential for agency. It is thus important to balance such institutional accounts with attention to agency.

Incorporation of concepts such as union identity helps to refine the insights of the institutional tradition by treating unions as dynamic entities capable of responding to change by adapting their identities to fit new conditions. For Hyman, union identities form part of a wider process of union-derived strategy and are to be defined as "Inherited patterns of ideology, discourse and programmatic commitment. Such identities bias contemporary responses to challenges and opportunities, but they contain internal tensions and contradictions which create the possibility of change" (Hyman 2001, 223). Union identities evolve within a given institutional context. The key issue here becomes the capacity to formulate a new union identity in an era of crisis and the degree of success in the utilization of existing resources to rearticulate trade union goals.

To understand the evolving nature of union identities, I draw on the concept of framing, adopted from social movement theory. I argue that the kind of framing process employed will largely depend on the self-identification of the union, its identity as it has evolved over time, and the resources available to it. Success in framing, in turn, depends largely on power constellations affecting trade unions. This study underlines the need to examine the process of framing, the emergence of a new union identity, and the constraints inhibiting its consolidation in a dynamic manner.

Understanding the relationship between institutional structures and agency-driven mobilization allows us to overcome dichotomies between idealized types of social partnership unionism and social movement unionism (Taylor and Mathers 2002). Reality is more complex. Although variations in trade union organization and functioning are undeniable, amalgamation of institutionalized unionism with innovative tactics to broaden its appeal and renew itself from within should not be viewed as an impossible task, as this paper will argue. Research on collective identity stresses how movements can promote new identities to transform themselves and gain power. A good way to understand such processes is by examining the relationship between macrostructures and the interactional processes leading to change (Polletta and Jasper 2001, 298-99).

\section{Collective Action and Framing Processes}

In seeking to explain how union activists utilize political opportunity structures and press for change by redefining union identity and extending the notion of solidarity, the concept of framing has important insights to offer. Following Goffman (1974), frames are defined 
as "schemata of interpretation that assist individuals in locating, identifying, receiving and labelling occurrences" (Goffman 1974, 21). Collective action frames are sets of beliefs and meanings that legitimize the activism of social movements and inspire its campaigning (Snow and Benford 1988), while "master frames" are sufficiently broad in scope, flexible, and inclusive to retain a high level of cultural resonance. They are useful in that they help organize and guide collective action. Moreover, they can help redefine social conditions previously deemed acceptable. This process is interactive as it results from continuous negotiation as to the shared meaning that the organization will adopt (Gamson 1992). It also relies on movement activism and contentious, since the generation of new frames may run counter to established frames as well as constructing new political opportunities (Benford and Snow 2000, 614).

The process of establishing a shared meaning for frames goes through three core tasks. First is diagnostic framing, which involves defining a situation as problematic, identifying the problem, and attributing blame by establishing some form of causality (Gamson 1992). Second comes prognostic framing, which identifies a solution and the suitable tactics and strategies to realize it (Evans 1997). Third is motivational framing, a call to arms or the articulation of a rationale allowing actors to undertake appropriate ameliorative action (Benford 1993). Frames are often made as a result of a challenge by movement opponents or bystanders as well as for strategic purposes in order to achieve a specific objective. By use of speech acts, movement members articulate otherwise disconnected events to form a coherent, compelling whole and amplify reality to highlight those events and occurrences deemed more significant (Benford and Snow 2000, 623-25). A final important category is that of frame alignment, which is about linking individual with collective interpretive frameworks and connecting the ideological aims of a movement with those of a potential group of adherents (Snow et al. 1986). Frame alignment can entail frame amplification to clarify and invigorate a frame, frame transformation to implant and nurture new values, and frame bridging, that is, the conscious linkage of two ideologically close but structurally unconnected frames.

For the purposes of this paper, frame extension, meaning the enlargement of a given frame to appeal to potential adherents (Tarrow 1992), is the most salient of alignment techniques. It will be argued that a process of frame alignment occurred within the Swedish trade union movement, whereby the class-based solidarity frame of LO was extended to incorporate gender-stemming grievances of the feminist movement. Such frame alignment can be very significant when social movements seek to persuade activists to engage 
in new types of action as a result of the inadequacy of old forms of activity (Beckwith 2001, 301). Women union activists moved from the diagnosis of gender inequality to motivational and, later on, prognostic framing by stressing the inclusive nature of the movement's values and the fact that genuine solidarity entailed a comradely approach to gender-induced inequalities that involved both men and women.

Not all framing is successful, however, and not all frames are equally powerful. Frame resonance depends on the consistency of the frame regarding the movement's rhetoric and practice as well as its ability not to contradict itself (Zuo and Benford 1995). Resonance is also a function of the frame's empirical credibility in peoples' everyday experience. The centrality of the frame in carriers' lives and its fit with the wider cultural milieu is of crucial importance in determining it success (Swart 1995). In Sweden's LO, as gender-based injustice became evident, feminist entrepreneurs drew from the cultural resources of the labor movement to make class and gender-based solidarity their new master frame.

Analyzing speech acts of policy entrepreneurs, major union, and party publications, I attempt to show how the establishment of a master frame premised on solidarity had reached the limits of its usefulness for female trade unionists by the 1980s. Diagnostic and then motivational framing was undertaken by feminist actors to bring about this frame alignment leading to a new LO identity. The creation of the women's pot in 2007 led LO to yet another stage in which a solution has been identified, namely a mechanism to permit a higher wage increase for female-dominated branches. The frame alignment has proven successful up to a point, but the challenge now is to reconcile the new frame of solidarity with the multiplicity of wage-bargaining structures and the concomitant multi-level alliances between unions.

Feminist scholarship has underlined the role of female political entrepreneurs in seizing opportunities to frame given political conditions in gendered terms (Baldez 2002). Using the example of a coal workers' strike, Beckwith (2001) has shown how unconventional tactics were used by activists to assert their rights and challenge conventional modes of action. Similarly, female union activists in Sweden employed their preferred decentralized and informal tactics in the 1980s and 1990s to highlight the need for a realignment of solidarity along class and gender lines. The significance of this case study lies not only with the high status of Swedish trade unions and the mass character of LO. Uniting a feminist and labor perspective is far from straightforward. Ferree and Roth (1998) have shown how an exclusive conceptualization of solidarity practiced by feminists 
and unionists, both in support of striking day care workers in Berlin, limited the success of both. This case study involves a more optimistic case of an inclusive solidarity that builds on multiple identities that the present article outlines.

\section{The Traditional Swedish Model and LO's Quest for Solidarity}

In 1889 , the trade union branch of the Social Democratic Party (Socialdemokratiska arbetarepartiet, SAP) formed LO, which, from the outset, adopted a political stance in favor of working-class demands and was active in consolidating SAP dominance in political life. Pushing for class equality, freedom, and solidarity as the principal values of the labor movement, LO commanded high leverage over SAP governments. In 1902, the private employers' confederation (Svenska arbetsgivareföreningen, SAF) was formed and the two organizations soon dominated the private sector in organizing workers and employers, respectively. With the so-called Basic Agreement (Huvudavtalet) of 1938, LO and SAF established a modus vivendi that rested on their authority over their respective affiliated members and a willingness to regulate the labor market based on collective agreements. The centralization of wage bargaining in the 1950s made the role of LO and SAF even more important (De Geer 1992).

The clearest example of LO's attempts to further solidarity is the Rehn-Meidner model. LO economists Gösta Rehn and Rudolf Meidner designed this plan in 1951 and SAP adopted it a few years later. Wage solidarity formed a key component of the model. Centrally coordinated wage bargaining, suggested by the SAF and accepted by LO, would allow the unions to strive for both wage increases and wage equality as the inter-union rivalry would disappear. Efficient and productive firms would be provided with extra labor supply and gain incentives to expand. Higher rates of growth would follow, raising competitiveness and enabling welfare state expansion. Inefficient firms would be hard-pressed by the profit squeeze (Locke and Thelen 1995, 344).

The adoption of the Rehn-Meidner model provided LO with a concrete means to pursue equality and solidarity. The implementation of the policy led to reduced wage discrepancies and class-based egalitarianism became a tangible goal. The Swedish model managed to deliver concrete benefits at all levels of trade unionism (elite decision-makers, constituent unions, and the rank and file). Nevertheless, the model failed to address the question of female disadvantages and outright discrimination. The discrepancy between egalitarian rhetoric and the high wage differentials between male 
and female employees would ultimately contribute to undermining the moral authority of LO as manifested, inter alia, in the drop in membership registered by the end of the 1980s, the first decline since the heyday of the Swedish model (Mahon 2002, 57). It is in this context that female union activists begin to assert the salience of their gender as constitutive of their identity and challenge the solely class-based character of LO.

By the 1980s, the original Swedish model had changed considerably. First, the growth of the white-collar confederation (Tjänstemmännens Centralorganisation, TCO) and the confederation of professional associations (Sveriges akademikers centralorganisation, SACO) meant that LO lost its near-monopoly of wage-earner representation. Second, post-war expansion of the public sector led to separate wage negotiations, with bargaining in the private sector taking place between LO, SAF, and the white-collar unions' cartel. In the public sector and at the regional and local level, the LO-affiliated Municipal Workers' Union (Kommunalarbetareförbundet, Kommunal) and the equivalent TCO and SACO unions negotiated with the Local Authorities Association and the County Councils Federation (Tsarouhas 2008, 93).

These changes undermined the solidaristic wage policy. Until the 1960s, LO-SAF agreements had defined the upper limits of whitecollar demands. From that point onward, they served merely as minimum acceptable limits, leading to an increasing difficulty on the part of LO to reconcile real wage increases with narrowing of wage differentials. In the same period, engineering employers embraced post-Fordist production techniques, leading to a blurring of the bluecollar-white-collar division in the sector (Mahon 1994, 294). This placed an extra burden placed on solidaristic wage policy as industrial LO unions saw their pay position worsen compared to whitecollar colleagues but could do little to stop the trend.

Meanwhile, most of Sweden's politicians, academics, and the media embraced the employer-originated division between the (male-dominated) "competitive" and (female-dominated) "sheltered" sectors of the economy, alleging that the "competitive," exportoriented, and industrial sector ought to be prioritized in wage bargaining. In this context, the LO-affiliated and influential, male dominated Metalworkers' Union (Metallarbetareförbundet, Metall) ${ }^{1}$ agreed to defect from centralized bargaining, concluding a separate agreement in 1983 with engineering employers in search of "just" compensation for the productivity increases its members had achieved. By the end of the 1980s, SAF as a whole embraced decentralized wage bargaining and dismantled its bargaining unit paving the way for a cross-class alliance (Swenson 1991) in the private sector and leading to acrimonious relations between public sector and engineering unions. The current 
Metall objections to the implementation of a women's pot have their origins in that era.

\section{The Emergence of Gender as a Distinct Category}

The notion of gender as subordinate to class has deep roots in Swedish social democracy. The otherwise pioneering work of Alva Myrdal on the role of women was part of an attempt to enhance women's rights within the male-dominated industrial structures of the Taylorist age (Hirdman 1994). It was only within this context that feminist aspirations could find their expression: women's emancipation was to come through labor market participation (Curtin and Higgins 1998, 73). The LO-SAF Women's Council in 1947 focused on related needs such as childcare rather than labor politics (Briskin 1999, 177). This body was disbanded by the late 1960s amidst the radicalization of the labor movement, to be replaced by a Family Council, a reflection of the understanding of women's role prevalent at the time (Lundqvist 1999, 587-88). The formal acceptance of equalization of male and female wages in 1960 can be seen as a manifestation of "a peculiar conception of rational economic adjustment" on the part of the unions (Curtin and Higgins 1998, 75). Finally, the Equality Agreement between LO, TCO, and SAF in the 1970s aiming at preventing discrimination in the workplace made little difference (Gelb 1989, 166).

Nevertheless, a gender-based approach to labor politics did emerge in the 1960s. This was to some degree a consequence of the feminization of labor, as the state commissioned research looking at women's problems in their capacity as wage-earners. It was also part of the growth in second waved feminism. Women's Life and Work, a 1962 study authored by Swedish and Norwegian sociologists, proved a watershed. For the first time, gender became subject to systematic research seeking to explain the twin challenge for women as bearers of family responsibilities and labor market participation (Dahlström et al. 1962). It was at this time that the concept of gender equality, jämställdhet as distinct from the general word for equality jämlikhet, was introduced, distinguishing gender from class inequality (Ahlberg, Roman, and Duncan 2008, 82).

The goal of state legislation was to reconcile the double identity of women to enable the reproduction and distribution structure of the Swedish model. It is in that context that state intervention in support of women's rights took place. The most important of those measures were the introduction of individual taxation in 1970, a gender-neutral parental insurance in 1975, the Gender Equality Act in 1979, and the introduction of an Equality Ombudsman in 1980 (Eduards 1991). 
The consensus-based type of Swedish policy-making facilitated the implementation of such measures, as gender equality became a point of rhetorical adherence for all mainstream parties and organizations (Lindvert 2007, 243). The labor movement began with the problem's diagnosis. For instance, the 1972 SAP party program reads: "Industrial development has led to more women entering the labour market, where they enjoy worse pay and working conditions than men... . The fight for equality, introduced by workers in the old capitalist society, has expanded to a fight for equal treatment of all citizens, whether they are men or women" (SAP 1972, 5).

These changes occurred at a time when the first cracks in the old model had become apparent, as strenuous work conditions and wildcat strikes called the status quo into question. Centralized Fordist relations of production inhibited local unions from making their wage claims explicit and from influencing work conditions (Mahon 1994, 292). At the same time, the rise of the feminist movement offered new opportunities to activists to extend the notion of solidarity toward women's needs in tandem with the registered dissatisfaction from the centralized functioning of LO.

\section{Gender Framing in the Labor Movement}

The role of activists. As noted above, one of the consequences of the post-war rise in public sector employment was the rising number of female employees organized by Kommunal. By the 1980s, Kommunal had replaced Metall as LO's biggest union. Indicative of LO attitudes on the gender issue is that until the 1980s, 80 percent of Kommunal's positions were filled by men although the malefemale membership ratio $(20: 80)$ was almost identical to today's, and the union had had a female majority since the 1950s (Curtin and Higgins 1998, 84). By 1980, women constituted 40 percent of LO membership, but only a quarter of Congress delegates, and had no representation in the General Council, the organization's executive body.

Ignoring such discrepancies was becoming increasingly difficult for the leadership but it took mobilization by feminist activists to acknowledge the need to integrate women more effectively in the movement. In 1987, a public inquiry into female representation in Swedish organizations threatened to lead to the introduction of a quota to raise the level of women in LO's representative organs (Curtin and Higgins 1998, 78-79). Important as such instances were, it was only when union activists took up the initiative that a new wage politics emerged that broadened the traditional frame of solidarity to include gender. It is only then that the very identity of 
LO came to be redefined away from an exclusive class-based orientation and toward an inclusive solidarity that encompasses feminist aspirations.

The election of Lillemor Arvidsson as the first female president of Kommunal-and first woman to head an LO union-in 1988 signaled a significant change in the latter's gender policies that spilled over to LO as a whole. Her contribution to the emancipation of women unionists underlines the point that favorable opportunities for change are only partly shaped by the external environment. They are also the result of agents' active engagement within the movement to alter perceptions whose time has passed (Tarrow 1989). Arvidsson did not campaign for gender equality on the basis of gender difference. Instead, she placed this within the larger context of Swedish social democracy aiming to appeal at men and women alike: "Those of us who defended the welfare state and the public sector as the main method of producing welfare goods believed that a humane, civilized society ought to include a large measure of gender equality and economic/social justice to function [properly]" (Arvidsson and Wettergren 1997, 25).

Arvidsson campaigned vigorously for the welfare of Kommunal members and especially women, many of whom had badly paid part-time jobs. Under Arvidsson's leadership, women's representation in Kommunal rose at all levels including the Executive Council, the union's second decision-making organ after Congress. By the early 1990s, women were a majority at all thirteen levels of Kommunal representation and task delegation (Higgins 1996). The Kommunal leader joined the LO Executive, the first woman to do so, and SAP executive in 1990-1991. When in 1990 the SAP government introduced a strike ban and wage freeze, Arvidsson resigned from her post in the party and Kommunal was the only LO union to oppose the government's plans. While she resigned from the union leadership in the same year due to health issues, her successor, Ylva Thörn, further pushed Kommunal toward a feminist orientation concerned with working conditions in the public sector and women's wages.

The work of Arvidsson is important on its own merit but carries special significance in relation to the context within which her activism occurred. Arvidsson was a role model through her activist campaigning and gained nationwide popularity with progressives when she openly criticized SAP for its governmental policy on welfare cuts and a wage freeze. As the only senior figure in the party open to protest, Arvidsson displayed a commitment to the universal welfare state and generously funded social services and gender issues that proved an inspiration for her successors and many LO activists. 
Pioneers like Arvidsson became role models for more activists who pursued the goal of gender equality through decentralized and informal means. The best example of such a structure is the "women's gang" (Tjejligan) initiated in the early 1990s. At a time when the SAP was in danger of losing power, LO saw the network as a saving grace. Although SAP lost the election, Tjejligan grew beyond the confines of the labor movement. It adopted informal ways of recruitment and campaigned vigorously on the local level, bringing women together and making their voices heard, especially against the policies of the centre-right administration (Briskin 1999, $165)$. The informal, bottom-up activism of local trade union feminists fits the "solidaristic work policy" adopted by LO in 1991 aiming to make new flexible work principles attractive to all wage earners (Mahon 1996). Women stood to benefit most from this approach as they tended to suffer from more limited training opportunities, lower pay, and worse work conditions compared to their male colleagues.

\section{The Impact of "Class and Gender"}

In 1991, LO started the publication of the Class and Gender series, which marked a turning point in the self-identification of the organization, as the very title challenged the labor movement's prioritization of class over gender. In conditions of change marked by wage-bargaining decentralization and a serious economic crisis, the first Class and Gender report asserted that women were disadvantaged compared to men from all classes. Among the drafters of the text was Wanja Lundby-Wedin of Kommunal, who would later become the first woman to lead LO. The same 1991 Congress amended LO statutes to include gender equality in all LO positions.

In the 1996 Congress, gender equality became official policy and a gendered impact assessment for all LO policies and administrative duties was introduced. Equality officers were established at confederal and union levels (LO 1996). Lundby-Wedin's declaration (2000) that LO ought to become a "feminist organization" reflected a symbolic move to demonstrate LO's new identity while at the same time acknowledging the structural roots of discrimination:

Power relations between the sexes mean that women have lower wages and also worse conditions in the workplace. . . . It is for that reason that we must recognize that class and gender are equally powerful reasons for oppression. This is also the reason why I declared that $\mathrm{LO}$ ought to become a feminist 
organization as a newly elected LO chairperson. (Lundby-Wedin cited in Pedersson 2008, 18)

The fourth Class and Gender report (2006) named three main goals to reach gender equality in the workplace: ending gender-based occupational segregation; giving women the right to work full time if they so wish; equalizing wages between men and women. The LO President remained loyal to the new solidarity frame developed by feminists that sees gender equality as part of the wider struggle for justice. In a May Day rally, she proclaimed

A broad understanding is needed if men and women, side by side, are to bring down the old power structures who have divided [us] and have led to unequal evaluations of men and women. Everyone, irrespective of gender, has to attach great importance to equal worth and equal value, in practice and not just according to law. (Lundby-Wedin 2006 cited in Norrby 2008)

\section{Gender-based Wage Politics in the Modern Era}

When the centralized policy practice of wage increases for all proved unsustainable, the possibility of opting for targeted increases by using a gender-based criterion of solidarity became more appealing. The old type of solidarity in wage politics was premised on wage increases for all, and women-dominated sectors had to display their "loyalty" to the system (Fransson and Thörnqvist 2006). Wage-bargaining decentralization after SAF's withdrawal and the concomitant increase in influence that LO unions experienced made the frame extension efforts by unions such as Kommunal more visible.

A 1993 report, which outlined LO's new role in coordinating the wage demands of its affiliated unions, called for more attention to be paid on wage differentials between men and women (Johansson and Magnusson 1998, 339). The policy of narrowing wage differentials by simply targeting extra increases for the low-paid was explicitly contested by Kommunal, who argued in favor of a supplement targeted at women (Curtin and Higgins 1998, 85). In line with this position, in the 1995 bargaining round, Kommunal introduced the so-called women's pot (kvinnopotterna) to offer an extra wage increase to professions dominated by women. Other LO unions such as Transport Workers Union (Svenska Transportarbetareförbundet, Transport), Retail Workers Union (Handelanställdas förbund, Handels), and Paper Workers Union (Svenska Pappersindustriarbetareförbundet, Pappers) refused, however, to back the demand. At the 1996 Congress, LO 
stressed that economic growth increased the living standards of all members and that economic policy should keep inflation at an average European level (LO 1996, 78-83). Resistance within some unions to the new larger frame was evident, and the compromise solution was to strive for extra wage increases for the lowest paid without explicitly targeting women. A gender-based approach to wage politics was, however, becoming clearer; the diagnosis of the problem had been made. It was now time to move from the diagnosis to action:

In the 1995 wage bargaining round LO unions called for an extra wage increase to women-dominated sectors. But it is not possible to eliminate unjust wage differentials between different sectors through temporary measures. To [yield positive] results, analogous measures ought to be taken year after year. This ought to become a crucial part of LO's solidaristic wage policy in the years to come. (LO 1996, 78, emphasis added).

As success in the new approach required the cooperation of the male-dominated unions, union feminists saw the need to frame the issue in terms of solidarity not only at the union level but also between men and women. Thus, for instance, LO stated that "The occupational categories in which most Swedish women are employed belong to the worst paid, but there are also men who are low paid. . . . The task of the trade union movement is to fight so that both women and men have jobs and just wages" (LO 1996, 85). For Kommunal, "To actively work for gender equality can mean that one will end up opposing prevailing conventions and invisible rules.... Men who are not in solidarity to their gender may receive support neither from men nor form women. [But] gender equality is . . . an important justice and democracy question for all (Kommunal 1999, 25). This emphasis was in line with the approach traditionally followed by the union movement.

Before the start of the 2001 bargaining round, LO recommended an annual target of 3.8 percent, a minimum of SEK 650 average monthly increase in the sector concerned and proportionally higher increases awarded to those earning less than SEK 15,000 a month (LO 2000, 4-5). The policy was fraught with difficulty as LO industrial unions had obtained a viable alternative to LO coordination [the Industrial Agreement (IA), discussed below] and could set different targets for the period concerned. The negative reactions voiced by those unions during the municipal workers' 2003 strike revealed a growing schism. In the 2004 bargaining round, LO followed the same procedure and united around a SEK 650 monthly wage increase or 3.2 percent and a minimum increase of SEK 350 for low earners. This time, individual unions did not make amendments to the text agreed at the LO level. The confederation soon 
realized that the measure failed to start rolling back male-female wage discrepancies. What is more, individual wage bargaining had further increased wage discrepancies between blue- and white-collar workers. Solidarity in wage politics was missing the target on both fronts.

Between 1994 and 2003 average wages rose 41 percent. For workers, however, it has been only 36 percent whereas it has been 44 percent for white-collar employees. . . . It is mostly women who are hit by low wages in the municipality and county sector. Partly [that is] because there are so many more women affected by these agreements and partly because women's wages are clearly lower on average. (LO 2004, 5)

Prior to the 2007 bargaining round, the main goal was to offer above-average wage increases to lowest-paid employees targeting overall monthly increases of SEK 825 or 3.9 percent. As about three quarters of all Swedish employees renegotiated their terms of work, this was a very important round. Coordinated wage strategy to benefit the worst-off was a priority for all unions, including IFMetall. The expanded solidarity frame could now count on the members' support too: a 2007 report showed that 88 percent of women and 78 percent of men within LO believed that male-female wage differentials were too large (LO 2007, 5).

Yet, the best method to narrow this gap remains contested. IFMetall put up a fight against a women's pot. Though it agreed that wage differentials based on gender are unacceptable, it felt that the best way to overcome this was by creating more opportunities for women to occupy better-paid posts. When the LO Presidium went public with its explicit demand for a women's pot of SEK 205 for full-time employees, IFMetall voiced its disapproval. In a 2008 report it stated "If the question of gender equality was to be reduced to a wage question that would lead to deadlock. The wage differences between men and women are also dependent on conditions prevailing in working life" (IFMetall 2008, 76).

Frame Alignment and the Limits to Success: Structural and Institutional Factors

There are numerous challenges ahead for the new frame and its concrete manifestation in a new politics of wage solidarity. Although Sweden does well in an EU-wide comparison of the unweighted pay gap between the two genders (it stands at 26 percent in the EU compared to 16 percent in Sweden), there is still a weighted pay gap (accounting for occupation, age, working time, 
and sector) of 8 percent (Statistics Sweden 2008). Moreover, women account for only 28 percent of high-income earners. ${ }^{2}$ Occupational segregation is striking. Only 14 percent of all employed women and 13 percent of all men work in occupations with equal sex distribution. Moreover, 51 percent of the female workforce is in the public sector, compared to only 19 percent of men (Fransson and Thörnqvist 2006, 612). It is in the public sector, and especially at municipal level, that the weighted pay gap stands at its highest, 9.4 percent (Mediation Office 2008). Women members of LO have been hit particularly badly from cuts in public expenditure and 91 percent of them, about 750,000 people, belong to the lowest paid category of employees (LO 2006, 5).

Making gender-based wage politics acceptable has not been a straightforward process and remains a work in progress. First, the women's pot is yet to be accepted by IFMetall. In the report submitted to Congress in 2008 cited above, IFMetall threatened that it would formally break ranks with LO coordination in 2010 should the women's pot be part of the LO demands (IFMetall 2008). In declaring its opposition, it had the support of other industrial unions. At the same time, the majority of representatives from the other unions defended the principle (Juntilla and Rosberg 2008). In this context, although IFMetall has little to gain from the pot, it eventually agreed to the common LO demands. In the 2010 round, these were a minimum monthly increase of SEK 620 or 2.6 percent on sector-wide average wages plus an equality pot of SEK 125 per month (LO 2009b).

Second, the creation of the IA has lowered the stakes for some LO unions to participate in wage-bargaining coordination. In 1997, the IA was signed by twelve employer organizations and seven trade unions of LO, TCO and SACO. The agreement set out to offer a new mode of regulating the labor market by avoiding industrial action, promoting industrial development, and enhancing profitability to secure sound wage growth. Ever since its first test in 1998, the IA became the wage-setting norm for the other sectors (Elvander 2002). LO industrial unions see the IA as a guarantee that the export-driven sector will lead wage demands. Coordination within LO has, for IFMetall, "a long history" but seems to offer little else in the current context. Crucially, IFMetall rejects detailed LO steering on wage negotiations. This is seen as undesirable because it risks alienating white-collar unions (IFMetall 2008, 77-80). At the same time, recent developments cast doubt on the viability of the IA. In the 2010 bargaining round, the white-collar unions within the IA struck a separate agreement with employers and a few weeks later the largest engineering employer, Teknikföretagen, announced its 
withdrawal from the IA (Bengtsson 2010). This poses yet another challenge for IFMetall and other LO industrial unions in their attempt to balance their wage demands between LO and its IA-related obligations.

Third, service-oriented unions have stated that the leadership role assigned to industrial unions does not have to hold forever, and that the growing role of services needs to be taken into account in wage bargaining. A clear example of the uncertain waters of Swedish industrial relations came in 2007. In contrast to previous bargaining rounds, Kommunal agreed to three-year wage increases higher than those agreed in the IA context and secured a "women's pot" worth around SEK 120-130 a month on average (Andersson 2007).

Finally, there is the issue of the TCO and SACO stance on the women's pot. TCO and SACO have always eschewed the kind of linkages to parties that LO has had, and still retains, with SAP. Also, they do not embrace the principle of class-based solidarity at the same time as campaigning for female wage equality. SACO has long campaigned for individualized bargaining reflecting the advanced bargaining power of its members. Within TCO, unions such as the Health Professionals Association (Vårdförbundet) have opted for individualized wage bargaining and accept growing salary dispersion so long as their (discriminated) female members, mostly nurses, receive salary increases reflecting their tasks and experience (Bäck 2009).

\section{Conclusions}

Maintaining an exclusively class-based conceptualization of solidarity, Sweden's LO had long refused to acknowledge that genderbased differences in the labor market reflected a structural problem. By the 1980s, however, conditions were ripe for a push to extend the confederation's solidarity frame in line with gender-based demands as feminist activists within the union movement campaigned vigorously for a redefinition of union identity along class and gender lines. Their efforts highlight the role of policy entrepreneurs in union mobilization.

Class solidarity could now be supplemented by a gender dimension that went beyond legal neutrality in equal opportunity. The intensive work of activists led to the eventual transformation of LO insofar as the gender-egalitarian norm acquired a practical form of solidarity in wage bargaining. The acceptance of a women's pot in 2007 comes following repeated calls by LO to find creative new ways to bridge the gender wage gap. Early signs are promising. A 2009 LO report shows that over 2007 and 2008, female wage 
increases were 8.7 percent compared to 8.3 percent for men, resulting from the introduction of the women's pot. Also, between 2004 and 2008, the pay gap for blue-collar workers in the private sector has fallen from 6.1 to 4.8 percent (LO 2009a). Such gender-based egalitarianism legitimizes LO's newfound interventionism in wage politics. It also sits well with the confederation's tradition of solidaristic bargaining that dates from the Rehn-Meidner Model and can thus be seen as legitimate due to its association with a very successful part of the labor movement's history.

The empirical analysis has shown, however, that gender-based wage politics faces multiple challenges. Union density for blue-collar workers has dropped from 88 percent in 1995 to 71 percent in 2009 (LO 2009a). The centre-right government, elected in 2006, has been accused of contributing to this decline by changing the eligibility criteria for unemployment insurance and making participation in union-administered funds much more costly. Should the negative trend continue, LO's role in labor market regulation will come into question, not least from TCO and SACO unions and private sector employers.

In this and other battles, $\mathrm{LO}$ needs to present a united front. While gender framing has been successful in enlarging the scope of solidarity, acquiring a tangible form in the shape of a wage-bargaining strategy is challenged by some unions. Recognizing the innovative nature of the women's pot and making sure that all unions are united around the reframed concept of solidarity in wage politics are a major challenge for LO in the period ahead, considering that differences between industrial and public sector/tradable sector unions are not new, and have recently become more animated following the latter's refusal to adopt the export sector's wage-setting norm.

The significance of the women's pot, therefore, lies not only in setting out a promising path of trade union renewal through innovative activism and concrete policy proposals. Its consequences are also likely to go beyond an internal union debate on measures to empower women and may result in the reorganization of industrial relations at national level as well.

\section{NOTES}

I am grateful to the editors of Social Politics and three anonymous referees for their invaluable suggestions and comments. My thanks are also due to Tore Fougner for helping me structure some of my thoughts at an early stage of writing, and to Ceren Yildiz and Deniz Aksoy for administrative assistance. All remaining errors are solely my own responsibility.

Dimitris Tsarouhas is Assistant Professor at the Department of International Relations, Faculty of Economic, Administrative and Social 
Sciences, Bilkent University, 06800 Bilkent, Ankara, Turkey. Tel: +90 312 290 2677; Fax: +90 312266 4326; E-mail: dimitris@bilkent.edu.tr. He is the author of Social Democracy in Sweden (London/New York: IB Tauris, 2008) and numerous articles on European politics.

1. In 2006, Metall merged with the Swedish Industrial Union (Industrifacket) to form IFMetall. I will be using the IFMetall acronym when referring to events after 2006.

2. High-income earners are defined those earning SEK 35,000 or more a month.

\section{REFERENCES}

Ahlberg, Jenny, Christine Roman, and Simon Duncan. 2008. "Actualizing the 'Democratic Family'? Swedish Policy Rhetoric versus Family Practices." Social Politics, 15 (1): 79-100.

Andersson, Bosse. 2007. "Industriavtalets cementerade samsyn har börjat spricka." Dagens Nybeter, May 9.

Arvidsson, Lillemor, and Gunilla Wettergren. 1997. När Lillemor fick makten. Stockholm: Prisma.

Baccaro, Lucio, Harmann Kerstin, and Lowell Trurner. 2003. "The Politics of Labour Movement Revitalization: The Need for a Revitalized Perspective." European Journal of Industrial Relations, 9 (1): 119-33.

Bäck, Monica Andersson. 2009. "Nurses' Pay Formation in Swedish Health Call Centres." Gender, Work and Organization, 16 (5): 579-99.

Baldez, Lisa. 2002. Why Women Protest: Women's Movements in Chile. Cambridge: Cambridge University Press.

Beckwith, Karen. 2001. "Gender Frames and Collective Action: Configurations of Masculinity in the Pittston Coal Strike." Politics \& Society, 29 (2): 297-330.

Behrens, Martin, Kerstin Hamann, and Richard Hurd. 2004. "Conceptualising Labour Union Revitalization." In Varieties of Unionism: Strategies for Union Revitalization in a Globalizing Economy, eds. Carola M. Frege, and John Kelly, 11-31. Oxford: Oxford University Press.

Benford, Robert. 1993. "You Could Be the Hundredth Monkey: Collective Action Frames and Vocabularies of Motive within the Nuclear Disarmament Movement." The Sociological Quarterly, 34 (2): 195216.

Benford, Robert, and David Snow. 2000. "Framing Processes and Social Movements: An Overview and Assessment." Annual Review of Sociology, 26: 611-39.

Bengtsson, Tomas. 2010. “Första löneavtalet klar.” Dagens Nybeter, 20 March.

Briskin, Linda. 1999. "Unions and Women's Organizing in Canada and Sweden." In Women's Organizing and Public Policy in Canada and Sweden, eds. Linda Briskin, and Mona Eliasson, 147-83. Montreal, Canada: McGill-Queens University Press. 
Calmfors, Lars, and John Driffill. 1988. "Bargaining Structure, Corporatism and Macroeconomic Performance." Economic Policy, 3 (6): $14-61$.

Clegg, Hugh. 1976. Trade Unionism under Collective Bargaining. Oxford: Blackwell.

Curtin, Jennifer, and Winton Higgins. 1998. "Feminism and Unionism in Sweden.” Politics \& Society, 26 (1): 69-93.

Dahlström, E., H. Holter, S. Brun-Gulbrandsen, P. O. Tiller, G. Dahlström, and S. Thyberg. 1962. Kvinnors liv och arbete. Stockholm: SNS.

De Geer, Hans. 1992. The Rise and Fall of the Swedish Model. The Employers' Confederation, SAF, and Industrial Relations over Ten Decades. Chichester, UK: Carden Publications.

Diani, Mario. 1996. "Linking Mobilization Frames and Political Opportunity Structures: Insights from Regional Populism in Italy." American Sociological Review, 61: 1053-69.

Eduards, Maud. 1991. "The Swedish Gender Model: Productivity, Pragmatism and Paternalism." West European Politics, 14 (3): 166-81.

Elvander, Nils. 2002. "The New Swedish Regime for Collective Bargaining and Conflict Resolution: A Comparative Perspective." European Journal of Industrial Relations, 8 (2): 197-216.

Evans, John. 1997. "Multi-Organizational Fields and Social Movement Organization Frame Content: The Religious Pro-Choice Movement." Sociological Inquiry, 67 (4): 451-69.

Peter Fairbrother, and Charlotte Yates, eds. 2003. Trade Unions in Renewal: A Comparative Study. London/New York: Continuum.

Ferree, Myra, and Silke Roth. 1998. "Gender, Class and the Interaction between Social Movements." Gender \& Society, 12 (6): 626-48.

Franceschet, Susan. 2004. "Explaining Social Movement Outcomes." Comparative Political Studies, 37 (5): 499-530.

Fransson, Susanne, and Christer Thörnqvist. 2006. "Some Notes on Workplace Equality Renewal in the Swedish Labour Market.” Gender, Work and Organization, 13 (6): 606-20.

Frege, Carola M., and John Kelly. 2003. "Union Revitalization Strategies in Comparative Perspective." European Journal of Industrial Relations, 9 (1): 7-24.

Gamson, William. 1992. Talking Politics. New York: Cambridge University Press.

Gelb, Joyce. 1989. Feminism and Politics: A Comparative Perspective. Berkeley: University of California Press.

Goffman, Erving. 1974. Frame Analysis: An Essay on the Organization of the Experience. New York: Harper-Colophon.

Hamann, Kerstin, and John Kelly. 2007. "Party Politics and the Re-emergence of Social Pacts in Western Europe." Comparative Political Studies, 40 (8): 971-94.

Higgins, Winton. 1996. “The Swedish Municipal Workers' Union: A Study in the New Political Unionism." Economic and Industrial Democracy, 17 (2): 167-97. 
Hirdman, Yvonne. 1994. "Women - from Possibility to Problem? Gender Conflict in the Welfare State." Research Report, 3, Arbetslivscentrum.

Hyman, Richard. 2001. "Trade Union Research and Cross-National Comparison." European Journal of Industrial Relations, 7 (2): 203-32.

IFMetall. 2008. Lönepolitiska vägval: starka tillsammans för rättvisa lokalt och global [The road ahead in wage politics: strong together for local and global justice]. Stockholm: IFMetall.

Johansson, Anders L., and Lars Magnusson. 1998. LO andra halvseklet. Fackföreningelsen och sambället. Uddevala, Sweden: Atlas.

Juntilla, J. Catarina, and Laina Rosberg. 2008. "LO-facken slutter upp bakom Kommunal." Kommunalarbetaren, March 20.

Kommunal. 1999. Jämställdhets-programmet. Stockholm: Kommunal.

Lévesque, Christian, Murray Gregor, and Stéphane le Queux. 2005. "Union Disaffection and Social Identity." Work and Occupations, 32 (4): 400-22.

Lindvert, Jessica. 2007. "The Rules of the Game: Organizing Gender Policies in Australia and Sweden." Social Politics, 14 (2): 238-57.

LO. 1996. Utlåtanden del 2 - Kongressen 1996. Stockholm: LO. EO Print.

. 2004. Löner År 2004. Stockholm: LO.

2006. Gemensamma krav inför Avtal 2007. http://www.lo.se/ home/lo/home.nsf/unidView/1C5AAB823C59A90EC12572250043-

EA60/\$file/avtal2007webversion.pdf (accessed November 10, 2010).

- 2007. Röster om facket och jobbet 2/2007. Stockholm: LO.

2009a. Lönerraport År 2009. Stockholm: LO.

2009b. Gemensamma krav inför avtal 2009. Stockholm: LO.

Locke, Richard, and Katherine Thelen. 1995. "Apples and Oranges Revisited: Contextualized Comparisons and the Study of Comparative Labor Politics." Politics and Society, 23 (3): 337-67.

Lundqvist, Åsa. 1999. "Conceptualizing Gender in a Swedish Context." Gender \& History, 11 (3): 583-96.

Mahon, Rianne. 1994. "From Solidaristic Wages to Solidaristic Work: A Post-Fordist Historic Compromise for Sweden?" In Swedish Social Democracy in Transition, eds. Clement, Wallace, and Rianne Mahon, 285-314, Toronto: Canadian Scholars' Press.

Mahon, Rianne. 1996. "Women Wage Earner and the Future of Swedish Unions." Economic and Industrial Democracy, 17 (4): 545-86.

2002. "Sweden's LO: Learning to Embrace the Differences Within?" In Gender, Diversity and Trade Unions: International Perspectives, eds. Fiona Colgan, and Sue Ledwith, 48-72. London: Routledge.

Mediation Office. 2008. Avtalrörselsen och lönebildningen 2007. Stockholm: Medlingsinstitutet.

Norrby, A. 2008. "Kvinnors rättigheter har aldrig kommit av sig själv." https://www.kommunal.se/Kommunal/Nyheter/2006/Mars/Kvinnorsrattigheter-har-aldrig-kommit-av-sig-sjalv/. (accessed July 25, 2010). 
Pedersson, Svante. 2008. “LO-rörelsens framtid." http://www.pedersson. com/LOs\%20framtid.pdf (accessed April 12, 2010).

Polletta, Francesca, and James Jasper. 2001. "Collective Identity and Social Movements." Annual Review of Sociology, 27: 283-305.

SAP. 1972. Program Stadgar Utgivna 1972, Series: B 01, Vol. 6. Borås, Sweden: Sjuhärasbygdens Tryckeri AB.

Snow, David, E. Burke Rochford, Jr., Steven K. Worden, and Robert D. Benford. 1986. "Frame Alignment Processes, Micromobilization, and Movement Participation.” American Sociological Review, 51: 464-81.

Snow, David, and Robert D. Benford. 1988. "Ideology, Frame Resonance and Participant Mobilization." International Social Movement Research, 1: $197-217$.

Statistics Sweden. 2008. http://www.scb.se/Pages/TableAndChart 149084.aspx (accessed July 29, 2010).

Swart, William. 1995. "The League of Nations and the Irish Question: Master Frames, Cycles of Protest, and 'Master Frame Alignment'." The Sociological Quarterly, 36 (3): 465-81.

Swenson, Peter. 1991. "Bringing Capital Back in or Social Democracy Reconsidered: Employer Power, Cross-Class Alliances, and Centralization of Industrial Relations in Denmark and Sweden." World Politics, 43 (4): 513-44.

Tarrow, Sidney. 1989. Democracy and Disorder. Oxford: Oxford University Press.

—. 1992. "Mentalities, Political Cultures and Collective Action Frames: Constructing Meanings through Action." In Frontiers in Social Movement Theory, eds. Aldon D. Morris, and Carol McGlurg Mueller, 174-202. New Haven, CT: Yale University Press.

Taylor, Graham, and Andrew Mathers. 2002. "Social Partner or Social Movement? European Integration and Trade Union Renewal in Europe." Labor Studies Journal, 27 (1): 93-108.

Tsarouhas, Dimitris. 2008. Social Democracy in Sweden. London/ New York: IB Tauris.

Turner, Lowell, Katz Harry, and Richard Hurd, eds. 2001. Rekindling the Movement: Labor's Quest for Relevance in the 21st Century. Ithaca, NY: Cornell University Press.

Zuo, Jiping, and Robert Benford. 1995. "Mobilization Processes and the 1989 Chinese Democracy Movement." Sociological Quarterly, 36 (1): $131-56$. 